\title{
An Extraordinary Cause in the Etiology of Recurrent Massive Hemoptysis: Hughes-Stovin Syndrome
}

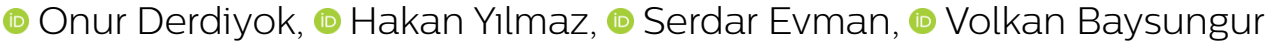

\author{
Department of Thoracic Surgery \\ University of Heath Sciences \\ Süreyyapaşa Chest Diseases and \\ Thoracic Surgery Training and \\ Research Hospital, İstanbul, Turkey \\ Submitted: 12.01.2019 \\ Accepted: 25.02.2019 \\ Correspondence: Onur Derdiyok, \\ SBÜ Süreyyapaşa Göğüs \\ Hastalıkları ve Göğüs Cerrahisi \\ Eğitim ve Araştırma Hastanesi Gögüs \\ Cerrahisi Kliniği, İstanbul, Turkey \\ E-mail: derdiyokonur@gmail.com

Keywords: Hughes-Stovin
syndrome; massive
hemoptysis; pulmonary
resection.
Co $\mathbf{0} \mathbf{O}$
Attribution-NonCommercial 4.0 International License.

\begin{abstract}
Hughes-Stovin syndrome is an extremely rare autoimmune clinical disorder that is characterized by deep vein thrombosis with multiple pulmonary and/or bronchial arterial aneurysms. This syndrome is an important cardiovascular status that may manifest Behçet's disease with systemic aneurysms. Here, we present the case of a 16-year-old female patient who suffered from recurrent life-threatening hemoptysis episodes due to right lower lobe pulmonary artery aneurysms and was finally treated with pulmonary resection.
\end{abstract}

\section{INTRODUCTION}

Hughes-Stovin syndrome (HSS) is a very rare clinical disorder that is characterized by thrombophlebitis and multiple aneurysms in pulmonary and/or bronchial arteries. However, other aneurysms in the systemic circulation can also be seen. There is no definitive criterion when considering the scarcity of this disease. ${ }^{[l]}$ The pathogenesis of this syndrome is still unknown. It is thought to be similar to Behçet's disease (BD) with systemic vascular involvement. ${ }^{[2]}$ Owing to the rarity of this disease, there is no standardized approach for treating it. ${ }^{[l-3]}$ The aim of this study is to contribute to the literature in light of our case of a female patient who underwent right lower lobectomy due to recurrent life-threatening hemoptysis.

\section{CASE REPORT}

A 16-year-old female patient presented to our clinic with a complaint of hemoptysis, which was recurring for the fourth time since the previous year. On physical examination, her blood pressure was $110 / 75 \mathrm{mmHg}$, heart rate was $95 \mathrm{bpm}$, body temperature was $36.5^{\circ} \mathrm{C}$, and respiratory rate was 25 breaths/min. Her medical history included a recurrent oral resuscitation of topical corticosteroid therapy in the three years since childhood, as well as an untreated genital ulcer six months earlier. Her biochemical laboratory parameters were within the normal limits. A posterior-anterior chest radiograph showed a minimal increase in intensity in the right lower region (Fig. I). Thoracic computerized tomography (CT) revealed a $36 \mathrm{~mm}$ round cystic lesion in the right lower lobe with suspicion of organized pneumonia, intraparenchymal cyst, or arteriovenous malformation (Fig. 2). Fiberoptic bronchoscopy revealed small bleeding and endobronchial lesions in the right lower lobe. There was no evidence of malignancy in the bronchoalveolar lavage and brush samples. No acid-resistant bacilli were observed. Agglutinin test for hydatid cysts was negative. No abnormality was detected on biochemical laboratory tests. CT angiogra- 


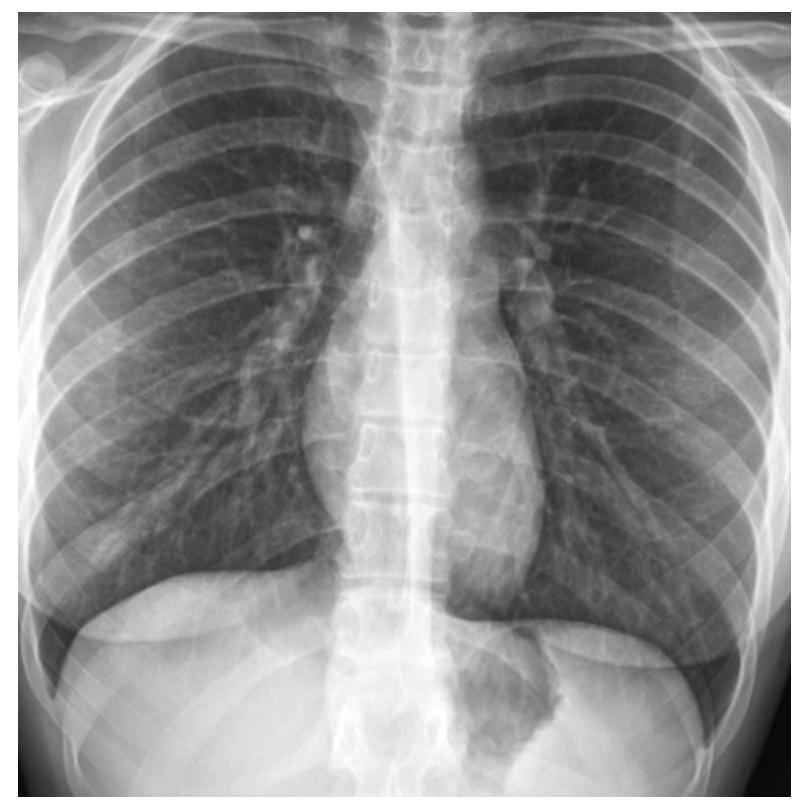

Figure 1. Minimal infiltration with a suspicious round-shaped lesion in the right lower zone.

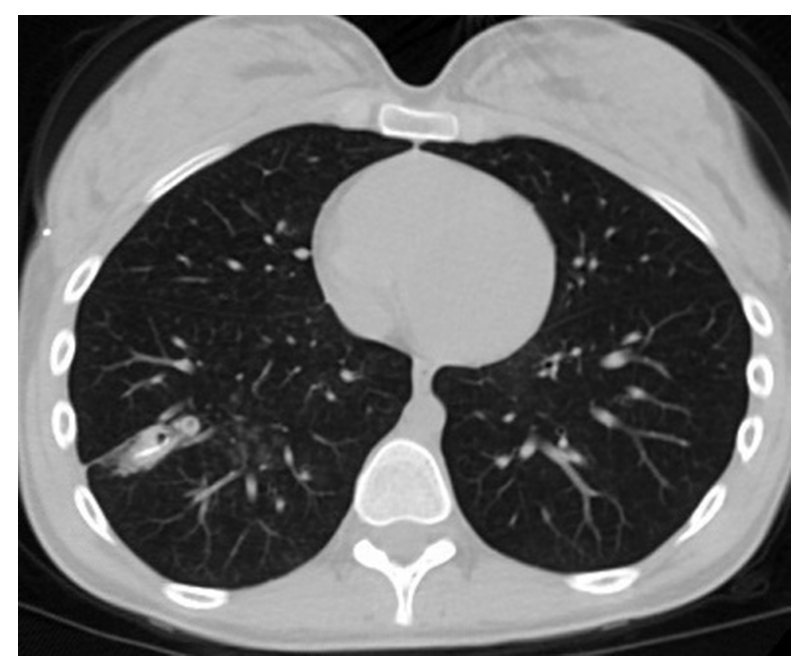

Figure 2. Thoracic CT revealing a lesion without caudal closure of about $36 \mathrm{~mm}$ in the lower part of the right lung.

phy revealed multiple pulmonary vascular abnormalities similar to arteriovenous malformations but diagnosed as pulmonary artery aneurysms.

The human leukocyte antigen (HLA B5I) test with paternity test was negative. The results of the perinuclear anti-neutrophil cytoplasmic antibody and circulating antineutrophil cytoplasmic antibody were also negative. The causes of the pulmonary artery aneurysms were investigated, but no standard approach to the etiology of the disease was recommended. After the diagnosis of HSS, the patient was started on systemic prednisolone and azathioprine therapy, and spiral embolization of the pulmonary aneurysms was performed. After eight months, massive hemoptysis attacks were detected. Recurrent CT angiography revealed two aneurysms in the right lower lobe; therefore, a right lower lobectomy was per-

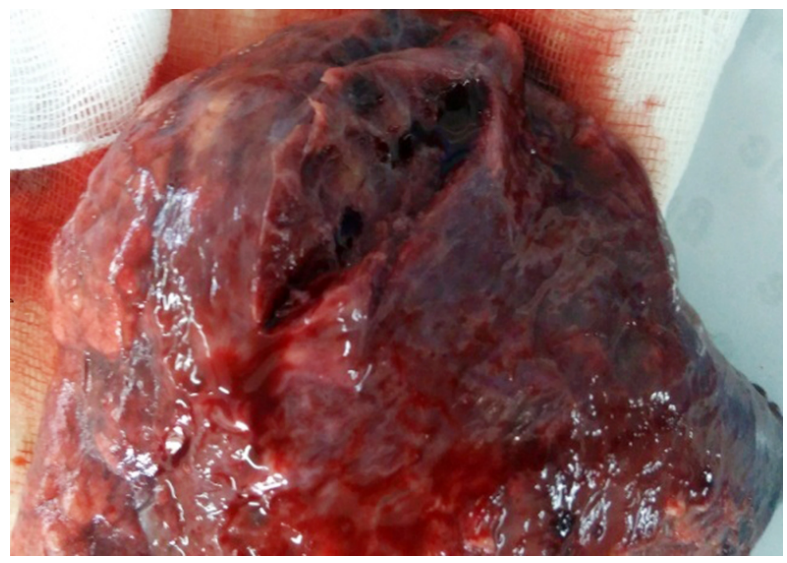

Figure 3. Right lower lobectomy specimen with a pulmonary aneurysm.

formed with thoracotomy for life-threatening hemoptysis (Fig. 3). Histopathology revealed a multitude of giant cells and granulomatous vasculitis and patchy laminar medial necrosis in all layers of the pulmonary wall. The patient was well and asymptomatic at II months postoperatively.

\section{DISCUSSION}

BD does not have pathognomonic diagnostic laboratory tests and is diagnosed on the basis of clinical findings. The most useful criteria for diagnosis are the International Working Group criteria published in 1990, which include recurrent oral ulceration plus two of the following: recurrent genital ulceration, ocular lesions, skin lesions, and positive paternity test results. ${ }^{[3]}$ Pulmonary artery involvement is rare, which affects approximately $5 \%$ of patients with BD and carries a high risk of mortality $(25 \%$ at seven years). It usually consists of pulmonary artery aneurysms associated with pulmonary artery thrombosis. The similarity between pulmonary artery and vein involvement is thought to be caused by thrombosis. Indeed, several anatomical and functional features of large venules are shared by pulmonary arteries: a thinner vascular wall, lower pressure, and greater compliance when compared to systemic arteries of comparable size. ${ }^{[4]}$

Similarities can be defined in BD when thought to be related to thrombosis and aneurysms. Some authors believe that HSS represents a cardiovascular manifestation of BD. HSS is described in the literature as a "cardiovascular manifestation of Behçet's disease," "incomplete Behçet's disease," and "a rare case of Behçet's disease". [5] However, our patient technically met the criteria for HSS during the first visit for hemoptysis, confirming the diagnosis of BD.

Treatment of HSS is not standardized given the fact that it is a rare disease. Given the similarities between the two syndromes, HSS is usually adapted along the lines of BD, ${ }^{[6]}$ whose treatment includes glucocorticoids administered as intravenous therapy followed by oral steroids. In addition, immunosuppressive drugs, particularly cyclophosphamide, are needed. Other immunosuppressants may be 
used, such as cyclosporin or azathioprine. The aim of this treatment is to stabilize the small aneurysms and even provide their stretches. ${ }^{[7]}$ Anticoagulation is a dilemma that can prevent the progression of thrombi but at the same time increase the risk and severity of hemorrhagic complications. In fact, anticoagulation is contraindicated because of the increased risk of lethal bleeding due to the potential rupture of the aneurysm, ${ }^{[6]}$ but in some cases it can be used with great caution in patients with deep vein thrombosis associated with life-threatening pulmonary embolism associated with an intracardiac thrombus. ${ }^{[4,6]}$ Surgical treatment is indicated for massive hemorrhagic masses due to a large pulmonary aneurysm composed of lobectomy or pneumonitis. ${ }^{[5,6]}$ In our patient, there was no positive response to medical treatment and embolization, and hence surgery was performed because of the hemoptysis attacks and the patient's life-threatening condition.

In conclusion, one of the rare causes of hemoptysis is HSS, whose clinical, radiological, and histopathological findings are similar to those of BD. There is no standard treatment guideline for this disease, as in BD. Anatomical resection is one of its treatment options, which should be kept in mind in medically resistant and life-threatening cases.

Informed Consent

Written informed consent was obtained from the parents of the patient for the publication of the case report and the accompanying images.

Peer-review

Internally peer-reviewed.
Authorship Contributions

Concept: O.D., H.Y.; Design: O.D., S.E.; Data collection \&/or processing: H.Y.; Supervision: S.E., V.B.; Fundings: O.D., V.B.; Analysis and/or interpretation: O.D.; Literature search: O.D., S.E; Writing: O.D.; Critical review: O.D.

Conflict of Interest

None declared.

\section{REFERENCES}

1. International Team for the Revision of the International Criteria for Behçet's Disease (ITR-ICBD). The International Criteria for Behçet's Disease (ICBD): a collaborative study of 27 countries on the sensitivity and specificity of the new criteria. J Eur Acad Dermatol Venereol 2014;28:338-47. [CrossRef]

2. Chalazonitis AN, Lachanis SB, Mitseas P, Argyriou P, Tzovara J, Porfyrides $\mathrm{P}$, et al. Hughes-Stovin syndrome: a case report and review of the literature. Cases J 2009;2:98. [CrossRef]

3. International Study Group for Behçet's Disease. Criteria for diagnosis of Behçet's disease. Lancet 1990;335:1078-80.

4. Hirohata S, Kikuchi H. Histopathology of the ruptured pulmonary artery aneurysm in a patient with Behçet's disease. Clin Exp Rheumatol 2009;27:S91-5.

5. Desbois AC, Wechsler B, Cacoub P, Saadoun D. Aortic inflammatory lesions in Behçet's disease. [Article in French]. Rev Med Interne 2016;37:230-8. [CrossRef]

6. Mikaniki E, Yusef Ghahari B, Mikaniki M. Frequency of ocular involvement in 100 cases of Behcet syndrome in Babol, North of Iran. Casp J Intern Med 2010;1:105-7.

7. Emad Y, Ragab Y, Shawki Ael-H, Gheita T, El-Marakbi A, Salama MH. Hughes-Stovin syndrome: is it incomplete Behçet's? Report of two cases and review of the literature. Clin Rheumatol 2007;26:1993-6. [CrossRef]

\section{Rekürrens Masif Hemoptizi Etiyolojisinde Olağanüstü Neden: Hughes-Stovin Sendromu}

Hughes-Stovin sendromu, çok sayıda pulmoner ve/veya bronşiyal arter anevrizması bulunan derin ven trombozu ile kendini gösteren son derece nadir bir otoimmün klinik hastalıktır. Bu sendrom, Behçet hastalığını sistemik anevrizmalarla gösterebilen önemli bir kardiyovasküler durumdur. Bu yazıda, sağ alt lob pulmoner arter anevrizmaları nedeniyle tekrarlayan hayatı tehdit eden hemoptizi atakları olan ve son olarak pulmoner rezeksiyon ile tedavi edilen 16 yaşında bir kadın olguyu sunuyoruz.

Anahtar Sözcükler: Akciğer rezeksiyonu; Hughes-Stovin sendromu; masif hemoptizi. 